\title{
Laboratory and pilot testing of electrocoagulation for removing scale- forming species from industrial process waters
}

\author{
M. C. Schulz; J. C. Baygents; *J. Farrell \\ Department of Chemical and Environmental Engineering, University of Arizona, Tucson, Arizona, USA \\ Received 3 July 2009; $\quad$ revised 19 August 2009; accepted 21 August 2009; $\quad$ available online 1 September
}

\begin{abstract}
This study investigated the performance of electrocoagulation using iron and aluminum electrodes for removing silica, calcium and magnesium from cooling tower blowdown and reverse osmosis reject waters. Experiments were conducted at both the bench and pilot scales to determine the levels of target species removal as a function of the coagulant dose. At the bench scale, aluminum removed the target compounds from both cooling tower blowdown and reverse osmosis reject more efficiently than iron. A $2 \mathrm{mM}$ aluminum dose removed $80 \%$ of the silica and 20 to $40 \%$ of the calcium and magnesium. The same iron dose removed only $60 \%$ of the silica and 10 to $20 \%$ of the calcium and magnesium. When operated with iron electrodes, pilot unit performance was comparable to that of the bench unit, which suggests that such systems can be scaled-up on the basis of coagulant dose. However, when operated with aluminum electrodes the pilot unit underperformed the bench unit due to fouling of the electrode surfaces after a few hours of operation. This result was completely unexpected based on the short-term experiments performed using the bench unit.
\end{abstract}

Keywords: Cooling tower blowdown; Electrocoagulation; Hardness removal; Silica removal; Water softening

\section{INTRODUCTION}

Electrocoagulation (EC) can remove a wide range of dissolved and colloidal contaminants from water without increasing the salinity of the treated water (Mickley, 2004; Behera et al., 2007). Conventional chemical coagulants, such as $\mathrm{Al}_{2}\left(\mathrm{SO}_{4}\right)_{3}$ and $\mathrm{FeCl}_{3}$, involve the addition of anions along with the metal cations that form the coagula. EC introduces the desired coagulating agent (e.g., $\mathrm{Al}^{3+}$ or $\mathrm{Fe}^{3+}$ ) without adding sulfate or chloride anions to the treated water. Additionally, the overall process has a minimal impact on the solution $\mathrm{pH}$ value, since the acid formed by the formation and precipitation of $\mathrm{Al}(\mathrm{OH})_{3}$ or $\mathrm{Fe}(\mathrm{OH})_{3}$ is removed by the cathodic reactions of oxygen reduction or hydrogen gas evolution. In contrast, chemical coagulants result in the net production of $\mathrm{H}_{2} \mathrm{SO}_{4}$ or $\mathrm{HCl}$ (Gu et al., 2009). EC units are mechanically simple devices, and in many common industrial applications, inexpensive to run, costing no more than a few dollars per thousand gallons of water treated (Lin et al., 2005; Gu et al., 2009).

Current reviews of EC (Chen, 2004; Mollah et al., 2004; Holt et al., 2005) cover the many uses of the

*Corresponding Author Email: farrellj@email.arizona.edu Tel.: +1 520621 2465; Fax: +1 5206216048 technology, which include the removal of organic compounds (Laridi et al., 2005; Lin et al., 2005; Can et al., 2006; Soltanali and Shams Haghani, 2008), metal ions (Adhoum et al., 2004; Kumar et al., 2004; Gao et al., 2005; Abdel-Ghani and El-Chaghaby, 2007), colloidal abrasive particles (Den and Huang, 2006), phosphate (Bektas et al., 2004; Akpor et al., 2007) and viruses (Zhu et al., 2005). Few studies have investigated treatment of potentially scale-forming species, such as silica, calcium and magnesium, especially at the concentrations present in industrial process waters. Two studies have investigated EC for dissolved silica removal, one as part of a dewatering process (Bayat et al., 2006) and one as a pretreatment for reverse osmosis (Den and Huang, 2008). However, neither of these studies investigated the relationship between coagulant dose and silica removal. One paper discussed the removal of calcium and total hardness from highly concentrated distillery wastes (Kannan et al., 2006). This study investigated the use of EC for removing silica, calcium and magnesium from cooling loop waters and from reverse osmosis reject (ROR) streams. These substances have the potential to form scales on heat transfer surfaces in cooling systems using recirculating 
water. If EC can effectively remove these species, ROR streams could be used in cooling tower loops and the volume of water requiring disposal as cooling tower blowdown (CTB) could be reduced. In particular, the goals of this study were to compare the performance of iron and aluminum blades and to compare results from bench scale and pilot scale experiments. Of primary interest is the relationship between contaminant removal and coagulant dose and how this relationship translates from the bench to the pilot scale. Both the pilot and bench studies were conducted during the summer of 2007 in Hillsboro, Oregon, USA at a semiconductor facility operated by the Intel Corporation.

\section{MATERIALS AND METHODS}

The CTB and ROR waters were taken from slipstreams tied into the main system lines at the semiconductor fabrication facility. The composition of the CTB and ROR waters are summarized in Table 1. When necessary, solution $\mathrm{pH}$ was adjusted by adding analytical grade (> $98 \%$ pure) sodium hydroxide or hydrochloric acid. Bench and pilot units were kept in a utility building with no temperature control and thus all experiments were carried out at an ambient outdoor temperature of $\sim 25^{\circ} \mathrm{C}$.

Bench tests were performed in a flow-through reactor (Powell Water Systems, Centennial Colorado) containing 9 electrodes in a parallel plate arrangement with interelectrode gaps of $0.4 \mathrm{~cm}$. The iron and aluminum electrodes were obtained from Powell Water Systems and were used as received. The electrode dimensions were $3.2 \times 34.0 \times 0.32 \mathrm{~cm}$ and with all electrodes in place, the void volume of the reactor was $0.35 \mathrm{~L}$. The reactor was operated galvanostatically using a Protek direct current power supply at current densities ranging from 0.3 to $9 \mathrm{~mA} / \mathrm{cm}^{2}$. Water to be treated was passed once through the reactor in an upflow manner at a rate of $0.35 \mathrm{~L} / \mathrm{min}$, yielding a hydraulic detention time of $1 \mathrm{~min}$. In tests reported on

Table 1: Typical range for target species concentration (mg/L), $\mathrm{pH}$ and total dissolved solids (TDS) in cooling tower blowdown and reverse osmosis reject streams

\begin{tabular}{lcc}
\hline & $\begin{array}{c}\text { Cooling tower } \\
\text { blowdown }\end{array}$ & $\begin{array}{c}\text { Reverse osmosis } \\
\text { reject }\end{array}$ \\
\hline $\mathrm{pH}$ & $7.5-8.0$ & $7.8-8.2$ \\
Silica & $40-50$ & $65-75$ \\
$\mathrm{Ca}$ & $17-23$ & $30-35$ \\
$\mathrm{Mg}$ & $4-6$ & $8-12$ \\
$\mathrm{TDS}$ & $620-815$ & $275-450$ \\
\hline
\end{tabular}

elsewhere (Schulz, 2008), hydraulic detention times between 1 and 3 min were found to give identical levels of target species removal for the same coagulant dose. Therefore, hydraulic detention time was not investigated as an experimental variable. In order to simulate steady state operation, effluent samples were taken at least 10 min after commencement of each experiment. All samples were magnetically stirred at $\sim 100$ revolutions per min for $0.5 \mathrm{~h}$ and then allowed to settle overnight. After settling, the liquid samples were vacuum filtered using $0.45 \mu \mathrm{m}$ cellulose nitrate filter paper. In all bench tests, triplicate samples were taken for each set of operating conditions.

Pilot tests were performed in a Powell water systems flow-through reactor using 73 electrodes with interelectrode gaps of $0.4 \mathrm{~cm}$. Each electrode had dimensions of $20.3 \times 50.8 \times 0.32 \mathrm{~cm}$ and with all electrodes in place the void volume of the reactor was $23 \mathrm{~L}$. The reactor was operated galvanostatically at current densities ranging from 1 to $9 \mathrm{~mA} / \mathrm{cm}^{2}$ using a built-in $220 \mathrm{~V}$ power supply. The pilot unit was operated in upflow mode with hydraulic residence times between 1 and $2 \mathrm{~min}$. The pilot unit was operated for approximately $1 \mathrm{~h}$ before sample collection to ensure invariant voltage and amperage readings and was run continuously during the daily testing periods of approximately $8 \mathrm{~h}$. The reactor also contained an air sparging apparatus that was used to inject air bubbles into the water as it passed between the electrodes. The air sparging was needed in order to fully oxidize $\mathrm{Fe}^{2+}$ to $\mathrm{Fe}^{3+}$ at high coagulant doses, and to prevent sedimentation of the coagula in the reactor. Electrodes were not pulled or rinsed between tests, nor was the electrode placement changed. The reactor was rinsed on an as needed basis with a $9 \%(\mathrm{w} / \mathrm{w})$ sulfuric acid solution, with a maximum 1 week interval between rinses. The rinsing was performed to break up and remove any scale in the reactor or on the electrodes. Analyses for dissolved species concentrations and total dissolved solids (TDS) were performed by Test America Laboratories in Beaverton, Oregon. Samples were collected and filtered on site, stabilized with nitric acid and stored at indoor ambient temperature $\left(22^{\circ} \mathrm{C}\right)$ until analysis.

\section{RESULTS AND DISCUSSION \\ Dose-Response with iron electrodes}

Figs. 1a and b show the removal of silica, calcium and magnesium from CTB as a function of the iron 
dose. The abscissa is expressed both in terms of charge loading in Coulombs per $\mathrm{L}(\mathrm{C} / \mathrm{L})$ and $\mathrm{mmol} / \mathrm{L}$ of iron (mM-Fe). The Faradaic relationship between coagulant dose and charge loading was verified in a previous investigation (Gu et al., 2009) and can be expressed as:

\section{$\operatorname{Dose}(m M)=$}

charge loading $(\mathrm{C} / \mathrm{L}) \times 1000(\mathrm{millimol} / \mathrm{mol})$

$\overline{96485\left(\mathrm{C} / \mathrm{mol}^{-}\right) \times \mathrm{z}\left(\mathrm{mol} e^{-} / \mathrm{mol} \text { metal ion }\right)}$

where, the moles of electrons are denoted by mol e-. In the case of Faradaic dosing of iron (i.e., $\mathrm{Fe}^{2+}$ ), $\mathrm{z}=2$. The data in Fig. 1 show strong agreement between results obtained at the bench and pilot scales. Silica removal reached $60 \%$ at approximately $2 \mathrm{mM}$-Fe and approached $90 \%$ at 5 mM-Fe. Removal of calcium and magnesium was less than that for silica and approximately $20 \%$
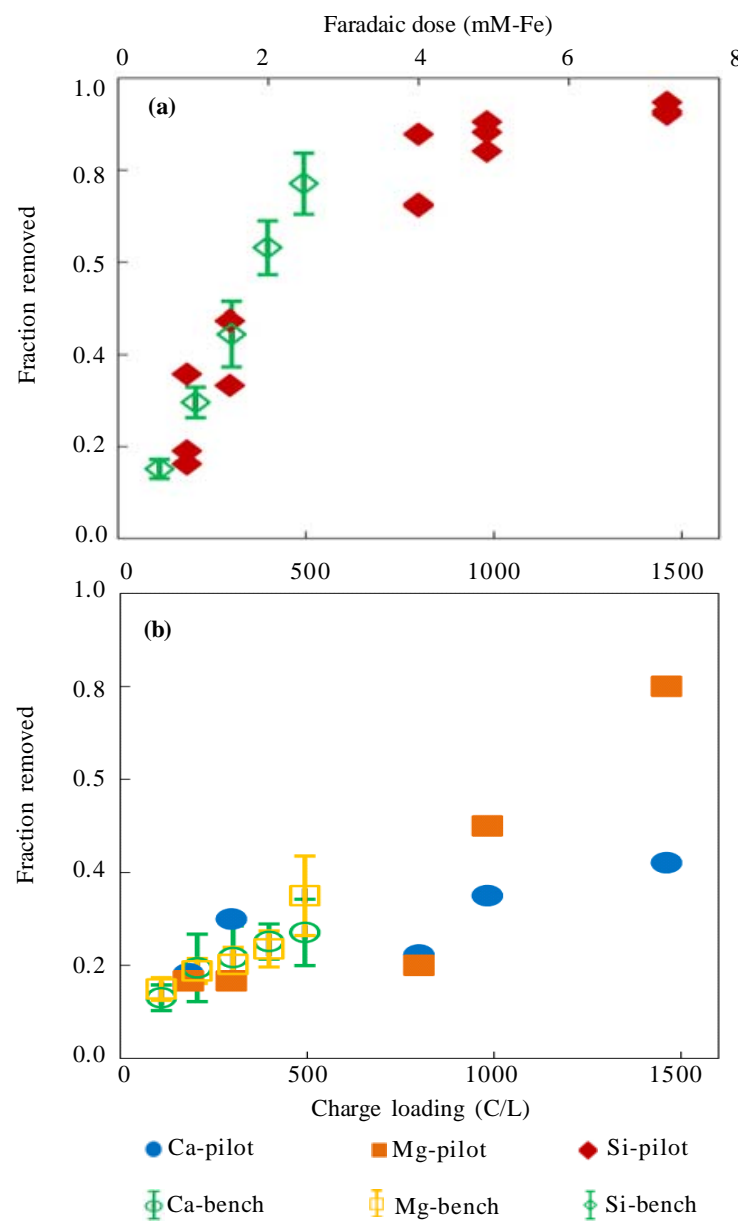

Fig. 1: Fraction of (a) silica and (b) Ca or Mg removed versus charge loading and coagulant dose for CTB. Error bars on the bench data indicate $+/$ - one standard deviation was removed for a $2 \mathrm{mM}$-Fe dose. Removal of TDS ranged from 4 to $20 \%$ and closely tracked the sum of the silica, calcium and magnesium removals.

The influence of the $\mathrm{Fe}^{2+}$ dose on silica, calcium and magnesium removal from ROR is shown in Figs. 2a and b. The dose range is half that explored for CTB, but the results indicate that relative to the bench test results, the pilot unit slightly underperformed with respect to silica removal, while doing slightly better on calcium and magnesium. Given the uncertainty in the data, it is probably not appropriate to draw strong distinctions between the performance of the bench and pilot units. The fractions of silica, calcium and magnesium removed from CTB and ROR were similar for a given coagulant dose. This indicates that differences in the overall composition of the waters
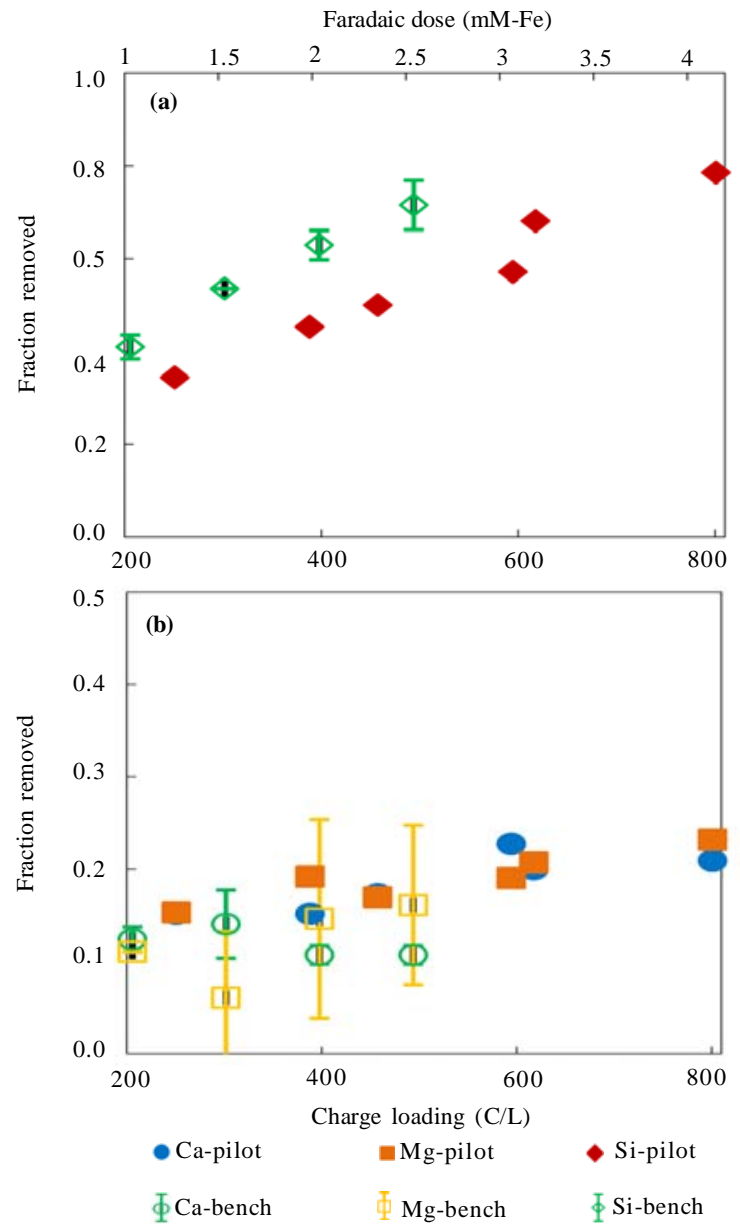

Fig. 2: Fraction of (a) silica and (b) Ca or Mg removed versus charge loading and coagulant dose for ROR. Error bars on the bench data indicate $+/$ - one standard deviation 
had little effect on the fraction of each target species removed.

\section{Dose-Response with aluminum electrodes}

Results for silica removal from CTB and ROR using aluminum electrodes are shown in Fig. 3. As was seen with the Fe electrodes, the bench results for ROR and CTB were very similar. In the bench tests, $80 \%$ of silica was removed at a $2 \mathrm{mM}-\mathrm{Al}$ dose, moving to $90 \%$ removal at $3 \mathrm{mM}-\mathrm{Al}$. The pilot removals, however, were substantially below those obtained with the bench unit. It is well-known that Faraday's law does not predict aluminum dosing by electrocoagulation (Picard et al., 2000; Canizares et al., 2005). NonFaradaic dosing results from chemical dissolution of the aluminum cathodes in the high $\mathrm{pH}$ solutions produced by reduction reactions on the cathode surface. Aluminum dosing as a function of charge loading in the bench reactor was determined in a previous investigation to be 1.8 times that given by Faraday's law (Gu et al., 2009). The $\mathrm{Al}^{3+}$ dose in the bench unit can therefore be calculated from the charge loading using equation 1 with $\mathrm{z}=3 \mathrm{~mol} \mathrm{e}$ - per $1.8 \mathrm{~mol}$ $\mathrm{Al}^{3+}$ or $\mathrm{z}=3 \div 1.8=1.67$. However, in the pilot unit, the $\mathrm{Al}^{3+}$ dose may not have had the same dependence on the charge loading as in the bench unit. During operation of the pilot unit, a gel formed on the cathodic

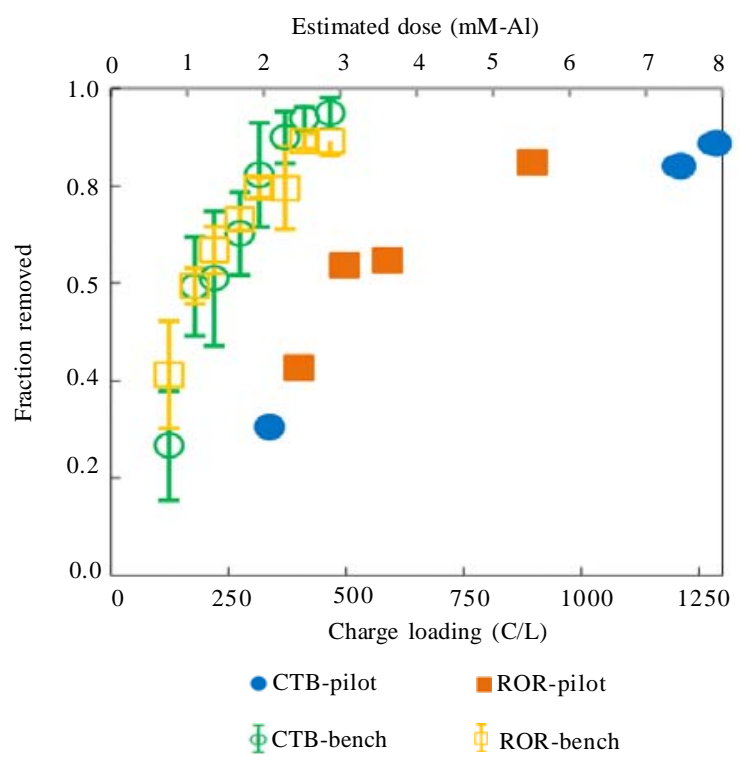

Fig. 3: Fraction of silica removed versus charge loading and estimated coagulant dose. Error bars on the bench data indicate $+/$ - one standard deviation faces of the electrodes, irrespective of the water source. The gel covered the entire cathode surface and appeared to form faster at higher power levels. Therefore, because this gel did not form in the bench unit, the $\mathrm{Al}^{3+}$ dose actually delivered to solution in the pilot unit was likely less than that in the bench unit. This may explain the shift in the dose-response relationship for the pilot as compared to the bench unit. Fig. 4 shows calcium and magnesium removals from CTB and ROR by aluminum electrodes. Comparison of Figs. 3 and 4 shows that calcium and magnesium removals were lower than those for silica from both the CTB and ROR. Calcium and magnesium were more effectively removed from CTB than from ROR, which may be due to the lower influent
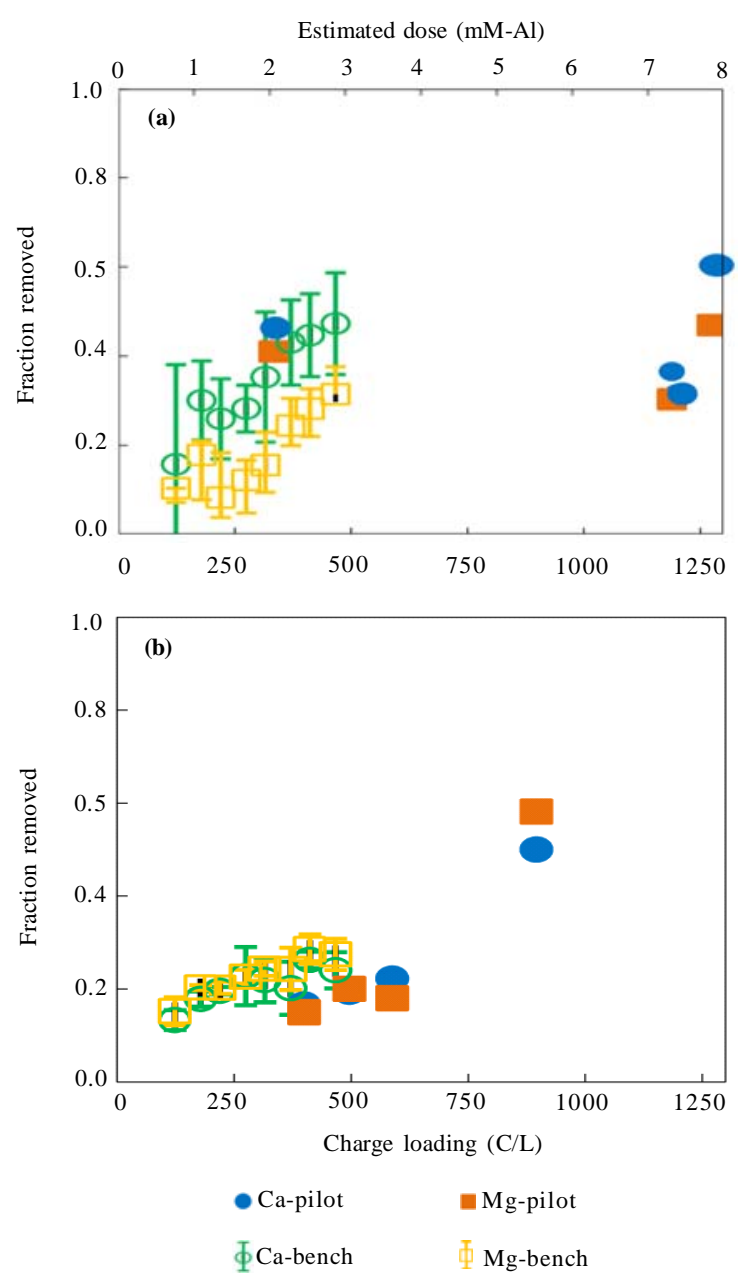

Fig. 4: Fraction of hardness ions removed versus charge loading and coagulant dose for (a) CTB and (b) ROR. Error bars on the bench data indicate $+/$ - one standard deviation 
concentrations of these species (Table 1 ) or the presence of proprietary additives in the CTB to prevent scaling, fouling and corrosion of heat transfer surfaces in the water recirculation loops. In a previous investigation, in the laboratory, phosphonate antiscaling compounds added to simulated CTB were found to increase hardness ion removals by EC. Calcium removal approached $50 \%$ and magnesium removal exceeded $30 \%$ at $3 \mathrm{mM}-\mathrm{Al}$ doses in CTB and the bench data suggest that removal may continue to increase in a roughly linear fashion over the next several mmol/L of coagulant. Removal of calcium and magnesium from ROR ranged from $20 \%$ to $30 \%$ in the 2 to $3 \mathrm{mM}$ dose range. Once again, removals in the pilot unit were below those for the bench unit at the same charge loading. The evidence again suggests that the observed gel formation was the reason for the disparity in performance.

\section{Iron versus aluminum electrodes}

One objective of this investigation was to compare the performance between $\mathrm{Fe}$ and $\mathrm{Al}$ electrodes. At the bench scale, aluminum blades removed the target compounds from both CTB and ROR more efficiently than iron blades. A $2 \mathrm{mM}$ aluminum dose removed $80 \%$ of the silica and 20 to $40 \%$ of the calcium and magnesium. The same iron dose removed only $60 \%$ of the silica and 10 to $20 \%$ of the calcium and magnesium. At the pilot scale, the iron electrodes performed as well as, or better than, the aluminum electrodes for the same estimated coagulant dose. The pilot reactor fouled to some degree with both electrode types, but it occurred more quickly and to a more severe degree with aluminum than with iron. The aluminum fouling was primarily due to the gel that formed on the cathode surfaces during the course of normal operation, whereas iron fouling was due to insoluble particulates settling in the reactor. The level of fouling with aluminum is an important factor to consider in scale-up, as this resulted in channeling and improper flow through the unit, which in turn may have affected coagulant dosing. Further, the fouling effectively doubled the amount of time the unit had to be taken out of service for maintenance. The quality and type of precipitates produced were different for iron and aluminum electrodes. At all dose levels, aluminum precipitates did not settle completely. Qualitatively, the precipitates had some cohesive properties, producing a gel on the surface of the filter paper. Furthermore, the aluminum sludge took up a greater fraction of the process volume and also tended to clog the $0.45 \mu \mathrm{m}$ cellulose nitrate filters used in these experiments. In contrast, the iron coagulated into discrete particles that settled rapidly after cessation of stirring. Furthermore, the iron coagula showed very little adhesion to the filter paper.

\section{CONCLUSION}

While numerous studies of EC have been conducted at the bench scale, comparatively few have been completed at the pilot or industrial scale. This study was conducted at the pilot scale in order to study potential maintenance and operational issues that could not be identified at the bench scale. For iron electrodes, performance at the bench scale was a good predictor of pilot unit performance. However, experiments revealed the issue of gel formation at the pilot scale with $\mathrm{Al}$ electrodes. Bench scale tests were conducted because these tests can be run and replicated in a rapid fashion, which allowed extents of removal along with their statistical uncertainties to be determined. On a fractional removal basis, one standard deviation for silica removal from CTB averaged 0.1 and for ROR it averaged 0.05 . Standard deviations for hardness ion removal were smaller than this, indicating that the results for both silica and hardness removal were consistent over a number of tests. This research showed that EC was effective at removing silica from two industrial waters, but was less effective for removing calcium and magnesium. Silica removals in excess of $80 \%$ could be achieved for $\mathrm{Fe}$ or $\mathrm{Al}$ doses of less than $4 \mathrm{mM}$. However, less than $40 \%$ of calcium and magnesium could be removed by either Fe or Al using a $4 \mathrm{mM}$ dose. Silica removal results were similar for ROR and CTB, but there was more variability in calcium and magnesium removals between the two water types. For iron electrodes, similar results were obtained at both the bench and pilot scales, while for aluminum, lower removals were observed in the pilot unit for the same charge loading as the bench unit.

\section{ACKNOWLEDGEMENTS}

Thanks to Steven Whitten for help with the experiments and to Zoe Georgousis, Allen Boyce and Chuck Graf for project guidance. Financial support for this project was provided by the University of Arizona Water Sustainability Program, the Arizona Water Institute and the Intel Corporation. 


\section{REFERENCES}

Abdel-Ghani, N.T.; El-chaghaby, G. A., (2007). Influence of operating conditions on the removal of $\mathrm{Cu}, \mathrm{Zn}, \mathrm{Cd}$ and $\mathrm{Pb}$ ions from wastewater by adsorption. Int. J. Environ. Sci. Tech., 4 (4), 451-456 (6 pages).

Adhoum, N.; Monser, L.; Bellakhal, N; Belgaied, J. E., (2004). Treatment of electroplating wastewater containing $\mathrm{Cu}^{2+}$, $\mathrm{Zn}^{2+}$ and $\mathrm{Cr}(\mathrm{IV})$ by electrocoagulation. J. Hazard. Mater., 112 (3), 207-213 (7 pages).

Akpor, O. B.; Momba, M. N. B.; Okonkwo, J. O.; Coetzee, M. A., (2008). Nutrient removal from activated sludge mixed liquor by wastewater protozoa in a laboratory scale batch reactor. Int. J. Environ. Sci. Tech., 5 (4), 463-470 (8 pages).

Bayat, O.; Kilic, O.; Bayat, B.; Anil, M.; Akarsu, H.; Poole, C., (2006). Electrokinetic dewatering of Turkish glass sand plant tailings. Water Res., 40 (1), 61-66 (6 pages).

Behera, S. K.; Rene, E. R.; Murthy, D. V. S., (2007). Performance of up - flow anoxic bioreactor for wastewater treatment. Int. J. Environ. Sci. Tech., 4 (2), 247-252 (6 pages).

Bektas, N.; Akbulut, H.; Inan, H.; Dimoglo, A., (2004). Removal of phosphate from aqueous solutions by electrocoagulation. J. Hazard. Mater., 106 (2-3), 101-105 (5 pages).

Can, O. T.; Kobya, M.; Demirbas, E.; Bayramoglu, M., (2006). Treatment of the textile wastewater by combined electrocoagulation. Chemosphere, 62 (2), 181-187 (7 pages).

Canizares, P.; Carmona, M.; Lobato, J.; Martinez, F.; Rodrigo, M. A., (2005). Electrodissolution of aluminum electrodes in electrocoagulation processes. Ind. Eng. Chem. Res., 44 (12), 4178-4185 (8 pages).

Chen, G., (2004). Electrochemical technologies in wastewater treatment. Sep. Purif. Tech., 38 (1), 11-41 (31 pages).

Den, W.; Huang, C., (2006). Parameter optimization and design aspect for electrocoagulation of silica nano-particles in wafer polishing wastewater. Water Sci. Tech., 53 (6), 187-194 (8 pages).

Den, W.; Huang, C., (2008). Removal of silica from brackish water by electrocoagulation pretreatment to prevent fouling of reverse osmosis membranes. Sep. Purif. Tech., 59 (3), 318-325 (8 pages).

Gao, P.; Chen, X.; Shen, F.; Chen, G., (2005). Removal of chromium (VI) from wastewater by combined electrocoagulation -electroflotation without a filter. Sep. Purif. Tech., 43 (2), 117-23 (7 pages).

Gu, Z.; Liao, L.; Schulz, M.; Davis, J. R.; Baygents, J. C.; Farrell, J., (2009). Estimating dosing rates and energy consumption for electrocoagulation using iron and aluminum electrodes. Ind. Eng. Chem. Res., 48 (6), 3112-3117 (6 pages).

Holt, P. K.; Barton, G. W.; Mitchell, C. A., (2005). The future for electrocoagulation as a localized water treatment technology. Chemosphere, 59 (3), 355-367 (13 pages).

Kannan, N.; Karthikeyan, G.; Tamilselvan, N., (2006). Comparison of treatment potential of electrocoagulation of distillery effluent with and without activated Areca catechu nut carbon. J. Hazard. Mater., 137 (3), 1803-1809 (7 pages)

Kumar, P. R.; Chaudhari, S.; Khilar, K. C.; Mahajan, S. P., (2004). Removal of arsenic from water by electrocoagulation. Chemosphere, 55 (9), 1245-1252 (8 pages).

Laridi, R.; Drogul, P.; Benmoussa, H.; Blais, J. F.; Auclair, J. C., (2005). Removal of refractory organic compounds in liquid swine manure obtained from a biofiltration process using an electrochemical treatment. J. Environ. Eng., 131 (9), 13021310 (9 pages).

Lin, C. J.; Lo, S. L.; Kuo, C. Y.; Wu, C. H., (2005). Pilot-scale electrocoagulation with bipolar aluminum electrodes for onsite domestic greywater reuse. J. Environ. Eng., 131 (3), 491-495 (5 pages).

Mickley, M., (2004). Pretreatment capabilities and benefits of electrocoagulation. United States Office of Naval Research, Washington, DC, USA.

Mollah, M. Y. A.; Morkovsky, P.; Gomes, J. A. G.; Kesmez, M.; Parga, J.; Cocke, D. L., (2004). Fundamentals, present and future perspectives of electrocoagulation. J. Hazard. Mater., 114 (1-3), 199-210 (12 pages).

Picard, T.; Cathalifaud-Feuillade, G.; Mazet, M.; Vandensteendam, C., (2000). Cathodic dissolution in the electrocoagulation process using aluminium electrodes. J. Environ. Monit., 2 (1), 77-80 (4 pages).

Schulz, M. C., (2008). Electrocoagulation applied to water conservation and waste treatment., M.Sc. Thesis, University of Arizona.

Soltanali, S.; Shams Hagani, Z., (2008). Modeling of air stripping from volatile organic compounds in biological treatment processes. Int. J. Environ. Sci. Tech., 5 (3), 353360 (8 pages).

Zhu, B.; Clifford, D. A.; Chellam, S., (2005). Comparison of electrocoagulation and chemical coagulation pretreatment for enhanced virus removal using microfiltration membranes., Water Res., 39 (13), 3098-3108 (11 pages).

\section{AUTHOR (S) BIOSKETCHES}

Schulz, M. C., M.Sc. student, Department of Chemical and Environmental Engineering, University of Arizona, Tucson, Arizona, USA. Email:mcschulz25@gmail.com

Baygents, J. C., Ph.D., Associate professor, Department of Chemical and Environmental Engineering and Associate Dean for Academic Affairs, College of Engineering, University of Arizona, Tucson, Arizona, USA. Email: baygents@u.arizona.edu

Farrell, J., Ph.D., Professor, Department of Chemical and Environmental Engineering, University of Arizona, Tucson, Arizona, USA. Email: farrellj@email.arizona.edu 